\title{
Consumers' Acceptance and Use of Information and Communications Technology: A UTAUT and Flow Based Theoretical Model
}

\author{
Saleh Alwahaishi',Václav Snášel ${ }_{2}$
}

\begin{abstract}
The world has changed a lot in the past years. The rapid advances in technology and the changing of the communication channels have changed the way people work and, for many, where do they work from. The Internet and mobile technology, the two most dynamic technological forces in modern information and communications technology (ICT) are converging into one ubiquitous mobile Internet service, which will change our way of both doing business and dealing with our daily routine activities. As the use of ICT expands globally, there is need for further research into cultural aspects and implications of ICT. The acceptance of Information Technology (IT) has become a fundamental part of the research plan for most organizations (Igbaria 1993). In IT research, numerous theories are used to understand users' adoption of new technologies. Various models were developed including the Technology Acceptance Model, Theory of Reasoned Action, Theory of Planned Behavior, and recently, the Unified Theory of Acceptance and Use of Technology. Each of these models has sought to identify the factors which influence a citizen's intention or actual use of information technology. Drawing on the UTAUT model and Flow Theory, this research composes a new hybrid theoretical framework to identify the factors affecting the acceptance and use of Mobile Internet -as an ICT application- in a consumer context. The proposed model incorporates eight constructs: Performance Expectancy, Effort Expectancy, Facilitating Conditions, Social Influences, Perceived Value, Perceived Playfulness, Attention Focus, and Behavioral intention. Data collected online from 238 respondents in Saudi Arabia were tested against the research model, using the structural equation modeling approach. The proposed model was mostly supported by the empirical data. The findings of this study provide several crucial implications for ICT and, in particular, mobile Internet service practitioners and researchers
\end{abstract}

Keywords: technology adoption; ict; acceptance; mobile internet; utaut model; flow theory.

Department of Computer Science, FEECS,VŠB-Technical University of Ostrava, I7. listopadu I5, 70833 Ostrava-Poruba, Czech Republic. Phone: +420 597325 252, Fax: +420 596919597.

e-mail: 'salehw@vsb.cz, ${ }^{2}$ vaclav.snasel@vsb.cz

ISSN: 07 I8-2724. (http://www.jotmi.org)

Journal of Technology Management \& Innovation (c) Universidad Alberto Hurtado, Facultad de Economía y Negocios. 


\section{Introduction}

Information and communications technology or information and communication technology (ICT), is often used as an extended synonym for Information Technology (IT), but is a more specific term that stresses the role of unified communications and the integration of telecommunications, computers as well as necessary enterprise software, middleware, storage, and audio-visual systems, which enable users to access, store, transmit, and manipulate information (Wikipedia, 20I2). ICT is an interdisciplinary area of research driven and shaped by the fast development of computing, communication, and Internet-related technologies, which have a great impact on our societies and daily lives. Over the last few decades there has been an increase in ICT research, which has changed and shaped the way societies and organizations operate and produce their goods and services.

The rapid advances in technology and the changing of the communication channels have changed the way people work and, for many, where do they work from. Hence, it is not only the generation of new technologies, but also its diffusion throughout the economy which affects productivity growth at the macro-level. Pilat and Lee (200I), showed that to capture the benefits of ICT it is not necessary to dispose of an ICT producing sector.Timely diffusion of new technology or, from the firm's point of view, its adoption is a key element to securing economic growth.

ICT use has proliferated throughout most sectors of the economies of developed countries. In the recent years, the mobile industry as a whole has been growing at an increasing pace (Liu \& Li, 20I I). Despite the recent downturn following the global financial crisis, the mobile industry has stayed relatively unscathed. With the so-called smart phone revolution, where advanced mobile devices are starting to see mass-adoption, the demand for more sophisticated mobile services is on the rise. Moreover, the penetration of mobile phone handsets and the diffusion of mobile technologies have been dramatically increasing in recent years. While it is still too early to predict that a mobile phone will become the ultimate converged device, people already carry their mobile handsets anytime and anywhere and use them for different purposes.

According to a recent study by on global mobile data traffic forecast, Smartphones represent only 12 percent of total global handsets in use today, but they represent over 82 percent of total global handset traffic (Cisco, 20I2). Moreover, the number of mobile phone subscriptions reached almost 6,000 million at the end of $20 \mathrm{II}$, representing a penetration rate of 86.7 percent worldwide and 78.8 percent in developing countries (ITU, 20I2). Hence, during the period from Sep. 20II to Sep. 20I2, on an average around 265,000 applications were registered in the US App Store (148Apps, 2012), and 140,000 application were registered in Android Market during same period (AndroLib, 20I2).

\section{A Review of Acceptance and Use of ICT}

As the use of information and communication technology (ICT) expands globally, there is need for further research into cultural aspects and implications of ICT. A better understanding of the factors contributing to the acceptance or rejection of information technology is the first step toward the solution of the problem.

User acceptance is often the pivotal factor and a central focus of Information Systems (IS) implementation research in determining the success or failure of an information technology product (Swanson 1988; Davis et al 1989; Thompson et all99I; Davis 1993; Igbaria 1993). Availability of information technology does not necessarily lead to its acceptance. Most information system failures result from a lack of user acceptance rather than poor quality of the system (Torkzadeh and Angulo 1992, Igbaria 1993, Davis 1993).

Previous research into user acceptance of information technology has mainly concentrated on users' attitudes toward acceptance while neglecting the role of social norms. It was also noticed that few IT characteristics were researched and these were not approached in a coherent manner (e.g., Davis 1986, Davis et al I989, Thompson et al I99I, Igbaria 1993, Davis 1993). Thus, it was recognized that the study would need to consider a broad range of IT characteristics and investigate the normative side of the equation besides that of attitudes toward usage.

Information and communication technology (ICT) use has proliferated throughout most sectors of the economies of developed countries. As mobile Internet plays an important role in the explosion of ICT, consumers' acceptance behavior needs to be understood. A greater understanding of the factors that impact this behavior could help organizations develop appropriate ICT adoption strategies. What little research there has been on ICT acceptance is general and this study aims to expand this field by probing the consumers' acceptance of information and communication technologies. In the technologically developed world, IT adoption is faced by barriers, such as the lack of top management support, poor quality IS design and inadequately motivated and capable users (Kwon and Zmud, 1987). In the developing world, the same barriers appear to be often impenetrable (Danowitz et al., 1995). In addition, problems found in developing counties are attributed to a lack of national infrastructure (Odedra et al., 1993), capital resources, or government policies set in place to prevent technology transfer (Goodman and Green, 1992).Although there are isolated reports of 
countries where sufficient resources and government support exist, the technology has failed to be effectively transferred (Atiyyah, 1989; Goodman and Green, 1992). While the uses of IT are varied, the common tie of technology use in the developing counties is one of limited diffusion (Goodman and Green, 1992).

From the practical perspective Saudi Arabia, the world's largest oil producer (CIA 2012) and it has the largest and fastest growth of ICT marketplaces in the Arab region (AIGhamdi et al, 2012). Hence, practitioners, managers and decision makers in the Saudi IT and telecommunication sectors are in need of information about how their customers act and react. The penetration of mobile phone handsets and the diffusion of mobile technologies have been dramatically increasing in recent years. While it is still too early to predict that a mobile phone will become the ultimate converged device, people already carry their mobile handsets anytime and anywhere and use them for different purposes.

\section{Research Methodology}

Research is an accepted investigation to find answers to a problem. Deciding on the appropriate research methodology is an essential part in defining the steps to be taken toward the completion of the research (Leedy, 2005). The methodology itself outlines all the essential steps to be followed in gathering and analyzing the data for the research. The first stage provided the research framework for the study based on a theory from social psychology and an application model of IT acceptance and use. The second stage led to the choice of the 'self-administered questionnaire' as a suitable research strategy and to a definition of the study sample. This stage provided the research data from 238 citizens of different educational and industrial backgrounds. In the third stage the data will be analyzed using different analysis techniques of varying levels of sophistication.

\section{Research Model and Theoretical Framework}

Agarwal (2000) defines technology adoption as the use, or acceptance of a new technology, or new product. In Information Technology and Information System (IT/IS) research, numerous theories are used to understand users' adoption of new technologies. Various models were developed including the Technology Acceptance Model (TAM), Theory of Reasoned Action (TRA), Theory of Planned Behavior (TPB), Innovation Diffusion Theory (IDT), Task Technology Fit (TTF), and recently, the Unified Theory of Acceptance and Use of Technology (UTAUT) are often used as the theoretical bases. Each of these models has sought to identify the factors which influence a citizen's intention or actual use of information technology.
TAM proposes that perceived ease of use and perceived usefulness are two main beliefs affecting user adoption (Davis, 1989). Due to its parsimony, TAM has been used to explain user adoption of various mobile services, including mobile payment (Chandra et al., 20l0), short message services (Lu et al., 20 I0), mobile shopping (Lu and Su, 2009), mobile ticketing (Mallat et al., 2009), and mobile Internet (Shin et al., 2010).

IDT notes that relative advantage, complexity, compatibility, trialability and observability predict user adoption (Rogers, 1983). IDT has been examined in the context of multimedia message services (Hsu et al., 2007), mobile payment (Mallat, 2007), and mobile banking (Lin, 20II). TTF proposes that only when task characteristics fit technology characteristics will user performance be improved (Goodhue and Thompson, 1995). TTF has been used to examine user adoption of location-based services (Junglas et al., 2008), and mobile work (Yuan et al., 20I0).

UTAUT was developed by Venkatesh et al. (2003) to predict user adoption of an information technology. UTAUT integrated eight theories, including the TAM, IDT, the theory of reasoned action (TRA), the motivational model, the theory of planned behavior (TPB), a model combining the TAM and TPB, the model of PC utilization and social cognitive theory (SCT). With empirical analysis, Venkatesh et al. (2003) found that performance expectancy, effort expectancy, social influence and facilitating conditions are the main factors determining user adoption. Among them, performance expectancy is similar to perceived usefulness and relative advantage. Effort expectancy is similar to perceived ease of use and complexity. Social influence is similar to subjective norm. Since its inception, UTAUT has been used to explain user adoption of a variety of information technologies, including location-based services ( $\mathrm{Xu}$ and Gupta, 2009), mobile technologies (Park et al., 2007), mobile banking (Zhou et al., 20I0), Internet banking (Im et al., 20I I), and health information technologies (Kijsanayotin et al., 2009). Due to the relatively low adoption rate of mobile services, extant research has paid much attention to prior work of Venkatesh (2003, 20I2) and Zohu (20II) when identifying the factors affecting mobile user behavior.

Performance Expectancy reflects the perceived utility associated with using mobile Internet. Mobile Internet frees users from temporal and spatial limitations, and enables them to acquire information or services at anytime from anywhere. This can improve users' living and working performance and efficiency. According to the expectation confirmation theory, when users' expectation is confirmed, they will be satisfied (Bhattacherjee, 200I). Thus performance expectancy will affect user satisfaction. Extant research has also noted the effect of perceived usefulness (similar to per- 
formance expectancy) on satisfaction (Bhattacherjee, 200I; Lee et al., 2007a). In addition, performance expectancy will also affect continuance intention.

Effort Expectancy reflects the perceived difficulty of using mobile Internet. The constraints of mobile terminals such as small screens and inconvenient input have made it relatively difficult for users to search for information on mobile Internet (Lee and Benbasat, 2004). If users need to invest great effort on learning to use or skillfully using mobile Internet, they cannot feel satisfied. Thus effort expectancy will affect user satisfaction. In addition, users may discontinue their usage if mobile Internet service providers cannot present an easy-to-use interface to them. Prior research has revealed the effect of perceived ease of use (similar to effort expectancy) on user satisfaction (Lee et al., 2007a) and continuance usage (Shin et al., 2010).

Social Influence reflects the effect of referees' opinion on individual user behavior (Zhou, 20l I). According to social influence theory, users tend to comply with other important referees' opinions (Bagozzi and Lee, 2002). Thus when others who are important to a user recommend him or her to use mobile Internet, he or she may follow their suggestions. Hong et al. (2008) also found that social influence has a significant effect on the continuance intention of mobile data services.

Facilitating Conditions mean that users have the resources and knowledge necessary to use mobile Internet. Users need to bear the costs of using mobile Internet, such as communication fees and service fees. In addition, they need to be equipped with necessary knowledge to operate mobile Internet, which represents an emerging technology. If users do not own these resources and knowledge, they may not continue their usage of mobile Internet (Zhou, 20l I). Perceived Value is defined as the consumer's overall assessment of the utility of a product based on perceptions of what is received and what is given (Zeithaml, 1988). In the case of mobile Internet, potential users would probably compare all the attributes of mobile Internet usage with prices of previous mobile phone calls and stationary Internet access. The price value is positive when the benefits of using a technology are perceived to be greater than the monetary cost and such price value has a positive impact on intention. Thus, we add price value as a predictor of behavioral intention to use a technology (Venkatech et al, 20I2).

Perceived Playfulness reflects the pleasure and enjoyment associated with using mobile Internet. Perceived enjoyment is an intrinsic motivation that emphasizes the usage process, whereas perceived usefulness is an extrinsic motivation that emphasizes the outcome (Davis et al., 1992). Users expect to acquire enjoyment when they adopt mobile Internet to obtain ubiquitous information and services. When this expectation is met, users will feel satisfied. Thus perceived enjoyment may affect satisfaction. O'Cass and Carlson (2010) also noted that flow affects user satisfaction with professional sporting team websites. Lee et al. (2007b) reported that flow affects online banking users' satisfaction. In addition, perceived enjoyment may also facilitate continuance usage. If users cannot obtain enjoyment from using mobile Internet, they may discontinue their usage due to an unpleasant experience. The effect of perceived enjoyment on user behavior has been validated in extant research (Koufaris, 2002; Dickinger et al., 2008).

Attention Focus reflects a user's immersion when using mobile Internet. Mobile users often perform multiple tasks on movement, such as listening to music and accessing mobile Internet. Thus their attention allocated to mobile Internet may be limited. If they cannot focus their attention, their experience may be affected (Zhou, 20l I). This may decrease their satisfaction and continuance usage intention. Koufaris (2002) also noted that concentration (similar to attention focus) affects online shoppers' return intention.

Behavioral Intention is defined as a person's perceived likelihood or "subjective probability that he or she will engage in a given behavior" (Committee on Communication for Behavior Change in the 2 Ist Century, 2002, p. 3I).With increasing experience, consumers have more opportunities to reinforce their habit because they have more time to encounter the cues and perform the associated behavior (Kim and Malhotra 2005). With increasing experience, routine behavior becomes automatic and is guided more by the associated cues (Jasperson et al. 2005). As a result, the effect of behavioral intention on technology use will decrease as experience increases. Figure I presents the research model as well as the proposed hypotheses and relationship between the eight constructs and the behavioral intentions to accept and use the mobile Internet.

The research study hoped to investigate the relative impact of factors contributing to mobile Internet as a mean of Information and Communications technology acceptance across several consumers with different ages, experience, and educational backgrounds. Davis et al (1989), Thompson et al (1991), Igbaria (1993), and Davis (1993) attempted something similar when investigating the acceptance of IT. Their experience indicated a sample size more than 100 would be needed if statistical analysis was to be conducted satisfactorily with control variables.

The research model includes eight factors. Each factor was measured with multiple items. All items were adapted from extant literature to improve content validity (Straub et al., 2004). Measurement items in the questionnaire covered the 


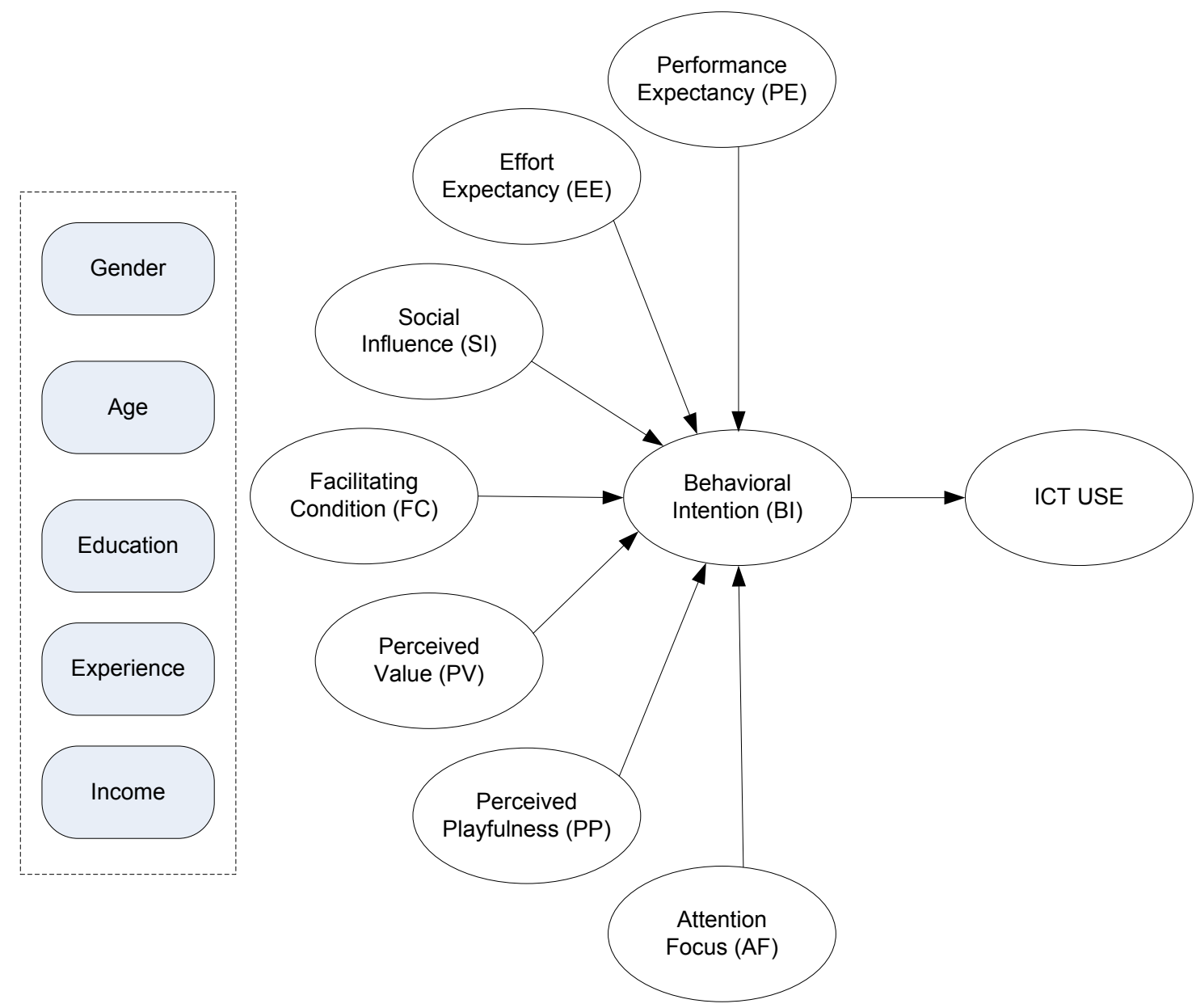

Figure I the proposed research model

constructs in the research model and were derived from existing literatures. Performance Expectancy (3 questions), Effort Expectancy (4 questions), Social Influence (2 questions), Facilitating Conditions (4 questions), and Behavioral Intentions (3 questions) were adapted Venkatesh et al. (2003). Perceived Playfulness (3 questions), and Attention Focus (3 questions) were adapted from adapted from Koufaris (2002), while the Perceived Value (3 questions) adapted from Venkatesh et al. (2012). An initial sample of 250 responses was received and after the removal of incomplete and duplicate responses, a total of 238 usable responses were included in the sample for analysis. A profile of the respondents is shown in Table I.

\section{Reliability and Validity Analysis}

To analyze the internal consistency of the constructs, the Cronbach's $\alpha$ was calculated and tested its reliability. The model reliability coefficient is 0.86 , which exceeded the 0.7 cut-off value as recommended by Nunnally (1978). Therefore, all constructs in this study demonstrated acceptable reliability.
A confirmatory factor analysis was conducted to check the statistical validity of the constructs. As shown in Table 2, all AVE values are greater than 0.5 , which indicates that the model had convergent validity. The square-root values of AVE were greater than the correlations between the corresponding constructs and the confidence intervals of the coefficients did not include I.0, which indicated that the constructs had discriminant validity.

\section{Structural Model}

Using structural equation modeling, the hypothesized relationships in the proposed research model were tested and analyzed. As seen in Table 3, the results showed that the $\square 2$ value of 469.99 (d.f. $=247$ ) with a $\mathrm{p}$-value of $.00 \mathrm{I}$ indicated a good model fit. In addition, fit indices such as the Normalized Fit Index (NFI = 0.87), Non-Normed Fit Index (NNFI $=0.91)$, Comparative Fit Index (CFI = 0.93) and Incremental Fit Index (IFI = 0.93) almost all exceeded the suggested level of 0.9 , indicating a good model fit. Furthermore, Hair, Anderson, Tatham, \& Black (1998) suggested that if the Root Mean 


\begin{tabular}{|c|c|c|c|}
\hline & Option & Count & Percentage (\%) \\
\hline \multirow{2}{*}{ Gender } & Male & 207 & 87.0 \\
\hline & Female & 31 & 13.0 \\
\hline \multirow{5}{*}{ Age } & Under 20 & 22 & 9.2 \\
\hline & $20-29$ & 158 & 66.4 \\
\hline & $30-39$ & 40 & 16.8 \\
\hline & $40-49$ & 16 & 6.7 \\
\hline & 50 and above & 2 & .8 \\
\hline \multirow{5}{*}{ Education } & Less than High School & 3 & 1.3 \\
\hline & High School & 64 & 26.9 \\
\hline & Some College/ Diploma & 20 & 8.4 \\
\hline & Bachelor Degree & 127 & 53.4 \\
\hline & Master Degree and Higher & 24 & 10.1 \\
\hline \multirow{6}{*}{$\begin{array}{c}\text { Income } \\
\text { (Saudi Riyals) }\end{array}$} & Less than 1000 & 95 & 39.9 \\
\hline & $1000-4000$ & 62 & 26.1 \\
\hline & $4001-8000$ & 24 & 10.1 \\
\hline & $8001-14000$ & 37 & 15.5 \\
\hline & $|400|-20,000$ & 9 & 3.8 \\
\hline & More than 20,000 & 10 & 4.2 \\
\hline \multirow{14}{*}{ Occupation } & Management, professional, and related & 11 & 4.6 \\
\hline & Computer, IT, and Telecommunications & 26 & 10.9 \\
\hline & Banking, investment, and Finance & 12 & 5.0 \\
\hline & Medical and Health Profession & 4 & 1.7 \\
\hline & Oil and Chemical industry & 2 & .8 \\
\hline & Logistics and Services & 2 & .8 \\
\hline & Education and Training & 10 & 4.2 \\
\hline & Engineering & 17 & 7.1 \\
\hline & Business & 8 & 3.4 \\
\hline & Government Employee & 8 & 3.4 \\
\hline & Private Business & 8 & 3.4 \\
\hline & Student & 111 & 46.6 \\
\hline & Unemployed/ Retired & 9 & 3.8 \\
\hline & Other & 10 & 4.2 \\
\hline \multirow{4}{*}{ Internet Experience } & Less than I year & 34 & 14.3 \\
\hline & I-2 years & 61 & 25.6 \\
\hline & 3-5 years & 79 & 33.2 \\
\hline & More than 5 years & 64 & 26.9 \\
\hline
\end{tabular}


Option

Count Percentage

$(\%)$

$\begin{array}{llccc} & \text { Never } & 13 & 5.5 \\ & \text { Once a Month } & 7 & 2.9 \\ \text { Usage Frequency } & \text { Once a Week } & 8 & 3.4 \\ & \text { 2-3 Times a Week } & 12 & 5.0 \\ & \text { 4-5 Times a Week } & 9 & 3.8 \\ & \text { Daily } & 93 & 39.1 \\ & \text { Many Times per Day } & 96 & 40.3\end{array}$

Table I Descriptive information of the sample

\begin{tabular}{|c|c|c|c|c|c|}
\hline Construct & Measure & Estimate & S.E. & C.R. & $P$ \\
\hline \multirow[t]{3}{*}{ Attention Focus } & AFI & .843 & .096 & 8.759 & 0.01 \\
\hline & AF2 & 1.287 & .148 & 8.699 & 0.01 \\
\hline & AF3 & 1.000 & & & \\
\hline \multirow[t]{3}{*}{ Behavioral Intention } & $\mathrm{BII}$ & 1.000 & & & \\
\hline & $\mathrm{B} 12$ & 1.384 & .110 & 12.628 & 0.01 \\
\hline & $\mathrm{BI} 3$ & 1.408 & .101 & |3.97| & 0.01 \\
\hline \multirow[t]{4}{*}{ Effort Expectancy } & EEI & .888 & .086 & 10.276 & 0.01 \\
\hline & EE2 & 1.154 & .097 & 11.936 & 0.01 \\
\hline & EE3 & 1.000 & & & \\
\hline & EE4 & 1.134 & .094 & 12.104 & 0.01 \\
\hline \multirow[t]{4}{*}{$\begin{array}{l}\text { Facilitating Condi- } \\
\text { tions }\end{array}$} & $\mathrm{FCl}$ & 1.523 & .282 & 5.398 & 0.01 \\
\hline & FC2 & 1.292 & .237 & 5.449 & 0.01 \\
\hline & FC3 & 1.000 & & & \\
\hline & FC4 & 1.104 & .217 & 5.088 & 0.01 \\
\hline \multirow{3}{*}{$\begin{array}{l}\text { Performance Expec- } \\
\text { tancy }\end{array}$} & PEI & .752 & .070 & 10.726 & 0.01 \\
\hline & PE2 & .873 & .076 & 11.516 & 0.01 \\
\hline & PE3 & 1.000 & & & \\
\hline \multirow[t]{3}{*}{ Perceived Playfulness } & PPI & 1.088 & .062 & 17.643 & 0.01 \\
\hline & PP2 & 1.031 & .050 & 20.417 & 0.01 \\
\hline & PP3 & 1.000 & & & \\
\hline \multirow[t]{3}{*}{ Perceived Value } & $\mathrm{PVI}$ & .989 & .089 & 11.089 & 0.01 \\
\hline & PV2 & .864 & .081 & 10.660 & 0.01 \\
\hline & PV3 & 1.000 & & & \\
\hline \multirow[t]{2}{*}{ Social Influence } & SII & .879 & .206 & 4.264 & 0.01 \\
\hline & $S I 2$ & 1.000 & & & \\
\hline
\end{tabular}

Table 2 Confirmatory factor analysis results 
Square Error of Approximation (RMSEA $=0.062$ ) is less than 0.08 , this represents a reasonable error of approximation.

The Root Mean Square Residual (RMR) in this study was equal to 0.054 , which is below 0.08 ; hence, it is regarded as evidence of good fit (Hair et al, 2006). In summary, the overall results suggested that the research model offered an adequate fit to the data.

We next examined the estimated coefficients of the causal relationships between constructs that validated the hypothesized effects. Figure 2 illustrates the estimated path coefficients and their significance in the structural model. Moreover, the measurement results presented in tables 4 and 5 , including information about reliability, validity, correlations, and factor loadings and the internal consistency reliabilities (ICRs) of multi-item scales modeled with reflective indicators was .75 or greater, suggesting that the scales were reliable. The average variance extracted (AVE) was greater than .70 in all cases and greater than the square of the correlations, thus suggesting discriminant validity. The pattern of loadings and cross-loadings supported internal consistency and discriminant validity.

\section{Discussion and Conclusion}

This research presented clearly shows the need for a thorough understanding of user attitudes and preferences towards ICT acceptance. As more technological innovations are introduced in rapid succession and an increased number of those innovations are failing, profound insights in the determinants towards adoption and use become more important. The research problem domain was discussed and the researcher's assumptions of the influential effects on mobile Internet acceptance and use are being explored.Also, the research questions that laid the foundations of this research study were explained. The factors affect end users adoption of mobile Internet, as a mean of ICT, have been investigated, analyzed and tested. The key results are summarized as below;
First, in this study, it has been proposed that the factors affecting end users adoption of ICT were: performance expectancy, effort expectancy, social influence, facilitating conditions, perceived value, perceived playfulness, attention focus, and behavioral intention. The survey was conducted with all the age groups who have experienced mobile internet. The survey subject were mainly constituted with 20-30s age group, the academic qualification of respondents were the highest in college graduate $53.4 \%$, and the majority of them were students as $46.6 \%$. It was also found that most of the participants were frequent users as $40.3 \%$ use mobile Internet many times daily with a high usage experience of 3-5 years for about third of the participants.

Second, analysis result showed that performance expectancy, perceived playfulness, social influence, and facilitating conditions among major variables affected significantly on behavioral intention which turns significantly on ICT use.

This research has some limitations. The first limitation concerns generalizability of the findings. As our study was conducted in Saudi Arabia, where mobile Internet is developing rapidly but is still in its early stages. Thus, our results need to be generalized to other countries that have developed mobile Internet. Second, most of our respondents were students. Although they represent the majority of mobile Internet users, future research can generalize our results to other samples, such as working professionals. Finally, we have studied only one type of Information and Communication Technology (i.e., mobile Internet). Future research can build on our study by testing the model in different countries, different user groups, and different technologies.

Finally, the framework presented within this article sets the goal to contribute to technology acceptance research by providing a comprehensive model, although it consists of a limited number of adoption and use determinants. This instrument allows supporting both ICT managers as policymakers with their innovation strategies, starting from a common framework.

\begin{tabular}{l|l|l}
\hline Fit indices & Recommended value & Result \\
\hline Chi-square/degrees freedom $\left(\chi^{2} / \mathrm{df}\right)$ & $<5.00$ (Hair et al., 1998) & 1.903 \\
\hline $\begin{array}{l}\text { Root Mean Square Error of Approxi- } \\
\text { mation (RMSEA) }\end{array}$ & $<0.08$ (Hair et al., 1998) & 0.062 \\
\hline Root Mean Square Residual (RMR) & $<0.08$ (Hair et al., 2006) & 0.054 \\
\hline Normed fit index (NFI) & $>0.90$ (Hu \& Bentler, 1999) & 0.87 \\
\hline Non-Normed Fit Index (NNFI) & $>0.90$ (Hair et al., I998) & 0.91 \\
\hline Comparative Fit Index (CFI) & $>0.90$ (Hu \& Bentler, 1999) & 0.93 \\
Incremental Fit Index (IFI) & $>0.90$ (Hu \& Bentler, 1999) & 0.93 \\
\hline
\end{tabular}

Table 3 Fit indices for structural model

ISSN: 07 I8-2724. (http://www.jotmi.org)

Journal of Technology Management \& Innovation (C) Universidad Alberto Hurtado, Facultad de Economía y Negocios. 


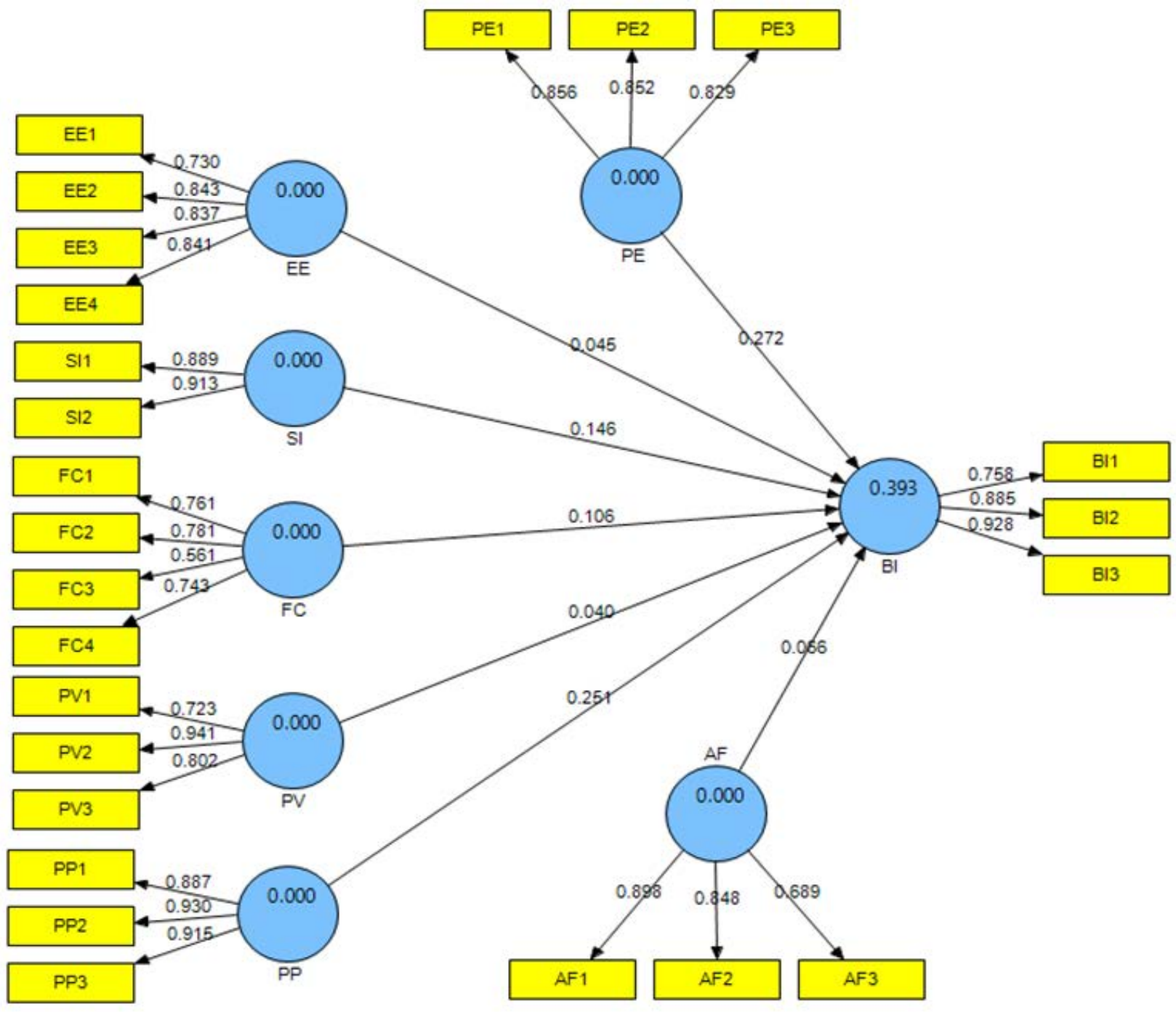

Figure 2 Results of structural modeling analysis

\begin{tabular}{|l|l|l|l|l|l|l|}
\hline Factor & AVE & $\begin{array}{l}\text { Composite Reli- } \\
\text { ability }\end{array}$ & R Square & $\begin{array}{l}\text { Cronbach's } \\
\text { Alpha }\end{array}$ & Communality & Redundancy \\
\hline AF & 0.6672 & 0.856 & 0 & 0.7837 & 0.6672 & 0 \\
$\mathrm{BI}$ & 0.7402 & 0.8946 & 0.3935 & 0.8223 & 0.7402 & 0.0202 \\
$\mathrm{EE}$ & 0.6628 & 0.8868 & 0 & 0.8299 & 0.6628 & 0 \\
$\mathrm{FC}$ & 0.514 & 0.8065 & 0 & 0.6894 & 0.514 & 0 \\
$\mathrm{PE}$ & 0.7153 & 0.8828 & 0 & 0.8043 & 0.7153 & 0 \\
$\mathrm{PP}$ & 0.8297 & 0.9359 & 0 & 0.8973 & 0.8297 & 0 \\
$\mathrm{PV}$ & 0.6838 & 0.865 & 0 & 0.8182 & 0.6838 & 0 \\
$\mathrm{SI}$ & 0.8114 & 0.8958 & 0 & 0.7682 & 0.8114 & 0 \\
\hline
\end{tabular}

Table 4 Internal consistency reliability 


\begin{tabular}{|c|c|c|c|c|c|c|c|c|}
\hline Construct & $\mathrm{AF}$ & $\mathrm{BI}$ & $\mathrm{EE}$ & FC & $\mathrm{PE}$ & PP & PV & $\mathrm{SI}$ \\
\hline $\mathrm{AFI}$ & 0.8981 & 0.2528 & 0.1387 & 0.168 & 0.2415 & 0.3445 & 0.0316 & 0.2233 \\
\hline AF2 & 0.8483 & 0.1807 & 0.0534 & 0.0387 & 0.1044 & 0.1484 & -0.0999 & 0.1576 \\
\hline AF3 & 0.6895 & 0.0612 & 0.0521 & 0.0307 & -0.0273 & 0.1086 & -0.0539 & 0.1554 \\
\hline BII & 0.2387 & 0.758 & 0.3323 & 0.3362 & 0.314 & 0.3666 & 0.0409 & 0.2003 \\
\hline $\mathrm{BI} 2$ & 0.198 & 0.8854 & 0.2786 & 0.3117 & 0.4683 & 0.4459 & 0.1728 & 0.3445 \\
\hline $\mathrm{BI3}$ & 0.1891 & 0.9284 & 0.3408 & 0.3674 & 0.5025 & 0.4753 & 0.1665 & 0.3193 \\
\hline EEI & 0.0515 & 0.248 & 0.7298 & 0.398 & 0.211 & 0.2826 & -0.0753 & 0.1572 \\
\hline EE2 & 0.0981 & 0.2827 & 0.8435 & 0.5185 & 0.3207 & 0.3123 & 0.0192 & 0.2404 \\
\hline EE3 & 0.1363 & 0.339 & 0.8369 & 0.5589 & 0.4079 & 0.3768 & -0.0113 & 0.2381 \\
\hline EE4 & 0.0726 & 0.3083 & 0.8406 & 0.5453 & 0.2841 & 0.3571 & 0.062 & 0.2155 \\
\hline $\mathrm{FCl}$ & 0.1718 & 0.3178 & 0.4247 & 0.7611 & 0.3258 & 0.3007 & 0.1364 & 0.1782 \\
\hline FC2 & 0.0162 & 0.3066 & 0.5626 & 0.7806 & 0.2462 & 0.3112 & -0.0402 & 0.1256 \\
\hline $\mathrm{FC} 3$ & 0.052 & 0.1509 & 0.2991 & 0.561 & 0.1748 & 0.3019 & 0.1386 & 0.2806 \\
\hline FC4 & 0.0949 & 0.3032 & 0.472 & 0.7435 & 0.305 & 0.3525 & 0.1088 & 0.1459 \\
\hline PEI & 0.1512 & 0.5067 & 0.3321 & 0.3383 & 0.8564 & 0.3831 & 0.1193 & 0.2867 \\
\hline PE2 & 0.2048 & 0.3804 & 0.3716 & 0.3308 & 0.8517 & 0.4405 & 0.1257 & 0.233 \\
\hline PE3 & 0.1156 & 0.3727 & 0.2665 & 0.2798 & 0.8289 & 0.3672 & 0.1201 & 0.1959 \\
\hline PPI & 0.2245 & 0.4185 & 0.3611 & 0.3662 & 0.4022 & 0.8866 & 0.1443 & 0.1825 \\
\hline PP2 & 0.2499 & 0.4774 & 0.4149 & 0.4508 & 0.4628 & 0.9303 & 0.1871 & 0.2369 \\
\hline PP3 & 0.3021 & 0.4729 & 0.3482 & 0.3661 & 0.4101 & 0.9151 & 0.1176 & 0.2171 \\
\hline PVI & -0.0111 & 0.0119 & -0.0496 & 0.0618 & 0.0759 & 0.1052 & 0.723 & 0.0965 \\
\hline PV2 & -0.0657 & 0.1699 & 0.0104 & 0.1245 & 0.1572 & 0.1623 & 0.9412 & 0.1336 \\
\hline PV3 & 0.0384 & 0.0937 & -0.0071 & 0.0454 & 0.0784 & 0.1203 & 0.8017 & 0.1922 \\
\hline $\mathrm{SII}$ & 0.1894 & 0.2891 & 0.2319 & 0.2066 & 0.2982 & 0.1983 & 0.214 & 0.8888 \\
\hline $\mathrm{SI} 2$ & 0.2123 & 0.3239 & 0.2435 & 0.2074 & 0.2246 & 0.2224 & 0.1021 & 0.9125 \\
\hline
\end{tabular}

Table 5 Loadings and cross-loadings

ISSN: 07 I8-2724. (http://www.jotmi.org)

Journal of Technology Management \& Innovation (c) Universidad Alberto Hurtado, Facultad de Economía y Negocios. 


\section{References}

I48APPS (2012). Count of Active Applications in the App Store. Accessed 10/09/2012, from http://148apps.biz/appstore-metrics/?mpage=appcount [Accessed August 9, 2012]

ALGHAMDI, R., Drew, S., Alhussain, T. (2012) A Conceptual Framework for the Promotion of Trusted Online Retailing Environment in Saudi Arabia, International Journal of Business and Management, 7(5): I40-149

ANDROLIB (20I2). Distribution of Apps and Games in Android Market. Accessed 10/09/2012, from http://www. androlib.com/appstatstype.aspx. [Accessed August 10,20I2]

ATTIYAH,H.S,(1989). Determinants of Computer System Effectiveness in Saudi Arabian Public Organizations, International studies of management and organization, 19(2):85- 103

AGARWAL, R. (2000), Individual acceptance of information technologies. Framing the domains of IT management: Projecting the future through the past, 2000: p. 85-104.

BAGOZZI, R.P. and Lee, K.-H. (2002) Multiple routes for social influence: The role of compliance, internalization, and social identity. Social Psychology Quarterly, 65(3): 226-247.

BHATTACHERJEE, A. (200I) Understanding information systems continuance: An expectation-confirmation model. MIS Quarterly, 25(3): 35I-370.

CHANDRA, S., Srivastava, S.C. and Theng,Y.-L. (20I0) Evaluating the role of trust in consumer adoption of mobile payment systems:An empirical analysis. Communications of the Association for Information Systems, 27: 56 I-588.

CIA (Central Inelegance Agency) 20I2, The World Fact Book: Saudi Arabia. Retrieved from https://www.cia.gov/ library/publications/the-world-factbook/index.html] [Accessed September 2, 2012]

CISCO (2012). Cisco Visual Networking Index: Global Mobile Data Traffic Forecast Update, 20II-2016. Retrieved from http://www.cisco.com/en/US/solutions/collateral/ ns34I/ns525/ns537/ns705/ns827/white_paper_cl I-520862. html [Accessed August 7, 20I2]

DAVIS, F.D. (1989) Perceived Usefulness, Perceived Ease of Use, and User Acceptance of Information Technology. MIS Quarterly, 13(3): 319-340.

DAVIS, F.D., Bagozzi, R.P. and Warshaw, P.R. (1992) Extrinsic and intrinsic motivation to use computers in the workplace. Journal of Applied Social Psychology, 22( I4): I I I - I I 32.
DAVIS, F.D. (1993) User acceptance of information technology: system characteristics, user perceptions and behavioral impacts. Int. Journal of Machine studies 38, 475-487.

DANOWITZ, A., Y. Nassef, and S.E. Goodman. (1995). Cyberspace across the Sahara: Computing in North Africa. Communications of the ACM, 38(I2): 23-28.

DICKINGER, A., Arami, M. and Meyer, D. (2008). The role of perceived enjoyment and social norm in the adoption of technology with network externalities. European Journal of Information Systems, I7(I): 4-II.

FORNELL, C. and Larcker, D.F. (198I) Evaluating structural equation models with unobservable variables and measurement error. Journal of Marketing Research, I8(I): 39-50.

GOODHUE, D.L. and Thompson, R.L. (1995) Tasktechnology fit and individual performance. MIS Quarterly, 19(2): 213-236.

GOODMAN, S.E and Green, J.D(1992). Computing in the Middle East, Communication of ACM, 35(8): 2 I-25

HAIR, J. F., Anderson, R. E., Tatham, R. L., \& Black,W. C. (1995). Multivariate Data Analysis with Readings (4th ed). Upper Saddle River, NJ: Prentice Hall.

HAIR, J. F., Anderson, R. E., Tatham, R. L., \& Black,W. C. (1998). Multivariate Data Analysis (5th ed). Upper Saddle River, NJ: Prentice Hall.

HAIR, J. F., Black,W. C., Babin, B. J., Anderson, R. E., \& Tatham, R. L. (2006). Multivariate Data Analysis (6th ed). Upper Saddle River, NJ: Prentice Hall.

HSU, C.-L., Lu, H.-P. and Hsu, H.-H. (2007) Adoption of the mobile Internet: An empirical study of multimedia message service (MMS). Omega, 35(6): 7I5-726.

HU, L., \& Bentler, P. M. (1999). Cutoff criteria for fit indexes in covariance structure analysis: conventional criteria versus new alternatives. Structural Equation Modeling, 6(I): I-55.

IGBARIA, M. (1993) User Acceptance of Microcomputer Technology: An Empirical Test. OMEGA Int. J. of Mgmt Sci. $21(1): 73-90$.

IM, I., Hong, S. and Kang, M.S. (20II) An international comparison of technology adoption:Testing the UTAUT model. Information \& Management, 48(I): I-8.

ITU (20I2). Mobile industry growth forecast. Retrieved from http://www.onbile.com/info/mobile-growth-forecast

[Accessed August 13, 20I2]

ISSN: 07 I 8-2724. (http://www.jotmi.org) 
JASPERSON, J., Carter, P. E., and Zmud, R.W. (2005).A Comprehensive Conceptualization of the Post-adoptive Behaviors Associated with IT-enabled Work Systems, MIS Quarterly, 29(3): 525-557.

JUNGLAS, I., Abraham, C. and Watson, R.T. (2008) Tasktechnology fit for mobile locatable information systems. Decision Support Systems, 45(4): 1046-1057.

KIJSANAYOTIN, B., Pannarunothai, S. and Speedie, S.M. (2009) Factors influencing health information technology adoption in Thailand's community health centers: Applying the UTAUT model. International Journal of Medical Informatics, 78(6): 404-4I6.

KIM, S. S. and Malhotra, N. K. (2005).A Longitudinal Model of Continued IS Use: An Integrative View of Four Mechanisms Underlying Post-adoption Phenomena, Management Science, 5I(5): 74I-755.

KOUFARIS, M. (2002). Applying the technology acceptance model and flow theory to online consumer behavior. Information Systems Research, I3(2): 205-223.

KWON, T.H., Zmud, R.W. (1987). Unifying the fragmented models of information systems implementation. Critical Issues in Information Systems Research, 227-5I

LEEDY, P. D. (2005). Practical Research: Planning and Design (6th ed.). Upper Saddle River, N.J.: Prentice Hall.

LIU, Yong, and Hongxiu Li. (20I I). Exploring the impact of use context on mobile hedonic services adoption: An empirical study on mobile gaming in china. Computers in Human Behavior 27 (2) (3): 890-8.

LU, H.-P. and Su, P.Y.-J. (2009) Factors affecting purchase intention on mobile shopping web sites. Internet Research, 19(4): 442-458.

LU, Y., Deng, Z. and Wang, B. (2010) Exploring factors affecting Chinese consumers' usage of short message service for personal communication. Information Systems Journal, 20(2): I83-208.

MALLAT, N. (2007) Exploring consumer adoption of mobile payments -A qualitative study. The Journal of Strategic Information Systems, 16(4): 4I3-432.

MALLAT, N., Rossi, M., Tuunainen, V.K. and Oorni, A. (2009) The impact of use context on mobile services acceptance: The case of mobile ticketing. Information \& Management, 46(3): 190-195.
MILES, M.B. and Huberman, A.M. (1984). Qualitative Data Analysis: A Sourcebook of New Methods. California; SAGE publications Inc.Sage

NUNNALLY, J.C. (1978). Psychometric Theory. New York, McGraw-Hill.

ODEDRA,M., Bennett, M. , Goodman, S. , and Lawrie, M. (1993). Sub-Saharan Africa: a Technological Desert, Communications of the ACM, 36(2): 25-29.

PARK, J., Yang, S. and Lehto, X. (2007) Adoption of mobile technologies for Chinese consumers. Journal of Electronic Commerce Research, 8(3): 196-206.

PILAT, D. and F.C. Lee (200I), Productivity Growth in ICTProducing and ICT-Using Industries: A Source of Growth Differentials in the OECD?, STI Working Papers 200I/4, OECD: Paris.

ROGERS, E.M. (1983) Diffusion of innovations. New York, The Free Press.

SHIH, H. (2004). An empirical study on predicting user acceptance of e-shopping on the Web. Information \& Management, 4I, 3, 35I-368.

SHIN, Y.M., Lee, S.C., Shin, B. and Lee, H.G. (2010) Examining influencing factors of post-adoption usage of mobile Internet: Focus on the user perception of supplier-side attributes. Information Systems Frontier, 12(5): 595-606.

STRAUB, D., Boudreau, M.-C. and Gefen, D. (2004) Validation guidelines for IS positivist research. Communications of the AIS, 13: 380-427.

SWANSON, E.B. (1988) Information System Implementation: Bridging the Gap Between Design and Utilization, Homewood, III-IRWIN, Inc.

THOMPSON, RL., Higgins, CA and Howel I, J.M. (199I) Personal Computing:Toward a Conceptual Model ofUti lization. MIS Quarterly, I5(I): I25-I43.

TORKZADEH, G. and Angulo, I.E. (I992) The concepts and correlates of computer anxiety. Behaviour \& Information Technology, II, 99-108.

VENKATESH, V., Morris, M. G., Davis, G. B., and Davis, F. D. (2003). User Acceptance of Information Technology:Toward a Unified View, MIS Quarterly, 27(3): 425-478. 
VENKATESH,V., Thong, J.Y.L., and Xin, X. (2012). Consumer Acceptance and Use of Information Technology: Extending the Unified Theory of Acceptance and Use of Technology. MIS Quarterly, 36 (I): I57-I78

WIKIPEDIA (20I2). Information and communications technology. Retrieved from http://en.wikipedia.org/wiki/lnformation_and_communications_technology [Accessed September 17, 20I2]

XU, H. and Gupta, S. (2009) The effects of privacy concerns and personal innovativeness on potential and experienced customers' adoption of location-based services. Electronic Markets, 19(2-3): 137-149.

ZHOU, T., Lu, Y. and Wang, B. (2010) Integrating TTF and UTAUT to explain mobile banking user adoption. Computers in Human Behavior, 26(4): 760-767.

ZHOU, T., (20I I). Understanding mobile Internet continuance usage from the perspectives of UTAUT and flow. Information Development, 27 (3): 207-2I8, 